doi: $10.15330 / m s u c .2019 .21 .9-13$

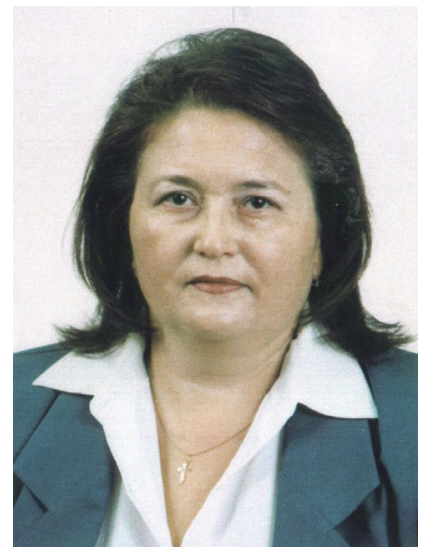

\author{
Ірина Зварич, \\ доктор педагогічних наук, старший науковий \\ співробітник, професор кафедри іноземної філології \\ та перекладу, \\ Київський національний торговельно-економічний \\ університет \\ (м. Київ, Україна) \\ Iryna Zvarych, \\ Doctor of Sciences (Pedagogics), Senior Staff \\ Scientist, the Department Professor Foreign \\ Philology and Translation, \\ Kyiv National University of Trade and Economics \\ (Kyiv, Ukraine) \\ iryna.zvarych7@gmail.com \\ ORCID ID 0000-0002-3772-4489
}

УДК 378.4

\title{
АНГЛОМОВНІ ВИСЛОВЛЕННЯ У ВИВЧЕННІ НАВЧАЛЬНОЇ ДИСЦИПЛІНИ
}

Анотація. У статті розглядаються англомовні висловлення як один із підходів до подальшого розвитку інтелектуальної діяльності студентів, ґрунтовного вивчення і глибокого осмислення навчального матеріалу; досліджено висловлення, які мають тіньові значення, висвітлюючи невичерпність національної історії, народної мудрості, світогляду; підкреслюється вважливість думок у процесі спілкування, взаєморозуміння в розв'язанні завдань професійного спрямування; виокремлюється важливість мови як засобу людського спілкування і найбільшого скарбу в розвитку освіти, яка є визначальним чинником культурного, економічного і політичного розвитку суспільства, держави.

Ключові слова: вищий навчальний заклад, осмислення, освіта, розвиток, еволюція, рівень якості знань.

\section{ENGLISH UTTERANCES IN THE STUDYING PROCESS OF LEARNING SUBJECT}

Abstract. The new technologies growth as well as democracy establishment and the vectors of humanistic progress in Ukraine led to the evolution of students' personalities as the main lever of modern development in the society and state. The main role in shaping modern student personality as a professional one and a citizen belongs to education. Education always reflects the interests of society and fulfills its social orders, forms the public demands for knowledge and progress prospects; changes under the influence of time, social, economic and other factors, demands the education quality service. One of the requirements for the education quality is to adjust students for their profession duties, in particular for study obtaining learning subject knowledge, profession skills and deep knowledge of state language proficiently.

This article deals with using utterances, in particular the proverbs, winged statements, sayings for developing the students' intellectual activity, comprehension of learning subject deeply with popular expressions bearing shadow meanings. The use of utterances makes every nation culture inexhaustible, highlights national history, folk wisdom, outlook of life, worldview; it emphasizes the importance of their usage for the development students' intellectual abilities, their creative approach to mastering the subject under study. Using the utterances in the studying process encourages students for learning subject thoroughly, creative thinking, the deep shadow understanding of the language statements' meaning.

Language is used to express thoughts, conceal the meaning, but the most often to replace thinking and development of students' activity for learning subject properly and it is considered to be a perfect and important means of human communication that helps young generation to share their thoughts, express their feelings, achieve mutual understanding, create spiritual values, in particular, deep comprehension of learning subject, and formation of personality. All people have no greater treasure than their speech, because only their language is the character, memory, spiritual power, history and evolution.

Keywords: Higher Learning Institution, comprehension, education, development, evolution, knowledge quality level.

\section{ВСТУП}

Постановка проблеми. Поява новітніх технологій, утвердження демократії та гуманістичних векторів поступу України зумовили розвиток особистості студентів як основного важеля сучасного прогресу суспільства і розвитку держави. Основна роль у формуванні сучасної особистості студента - професіонала і громадянина належить освіті. Освіта завжди відображає інтереси суспільства та виконує його соціальне замовлення, формує суспільний попит на знання і перспективи розвитку, змінюється під впливом часових, соціальних, економічних та інших чинників і потребує якісного обслуговування. Однією із вимог якості освіти - це підготовка студентів 
до виконання своїх професійних обов'язків, зокрема засвоєння ґрунтовних знань з навчальної дисципліни, опанування навчальним матеріалом і володіння державною мовою.

Історичний розвиток мови - це безперервний, тривалий і творчий процес, без різких стрибків або швидких перетворень. Зазвичай тривалий проміжок часу їі розвитку розділяють на історичні періоди, оскільки при вивченні історії будь-якої мови неможливо обійтися без такого поділу. Періодизація, яку пропонують ученілінгвісти, може здаватися штучною. І це цілком очевидно, бо мова в кожен період свого розвитку має особливі якісні ознаки, зазвичай структуру, що і дає право досліджувати певний період її історичної еволюції, зокрема, метафоричні висловлення. Наявність у сучасній англійській мові значної кількості висловлень пояснює ту велику роль, яку вони відіграли у збагаченні словникового складу й у становленні лексичних норм, оскільки вони дозволяють мові економити свої власні можливості номінації і сприяють подальшому розвитку словотворення.

Аналіз останніх досліджень і публікацій. Дослідники, як-от: С. Бреннан (S. Brennan), X. Kларк (H. Сlark), Д. Де Вал (D. De Vault), M. Стоун (M. Stone), X. Томасон (H. Thomason), удосконалили використання висловлень, зокрема систему, яка накопичує приклади вивчення для з'ясування неоднозначності, відстежуючи альтернативні інтерпретації в діалозі, включаючи різні уточнення. Звертаючи увагу на використання англомовних висловлень у спілкуванні, ми зробимо спробу висвітлити їхню роль у навчальному процесі, зокрема в опануванні навчальним матеріалом студентами, еволюцію інтелектуальної діяльності молоді, її ставлення до навчального предмета, підвищення рівня якості знань.

\section{МЕТА І ЗАВДАННЯ ДОСЛІДЖЕННЯ}

Мета статті - вивчити і розглянути англомовні висловлення як один із підходів до подальшого розвитку інтелектуальної діяльності студентів; дослідити висловлення, які мають тіньові значення; виокремити важливість мови як найбільшого скарбу в розвитку освіти, держави, суспільства.

\section{РЕЗУЛЬТАТИ ДОСЛІДЖЕННЯ}

Англійська мова постійно вдосконалюється і має багаторічну історію. Вона багата на ідіоми, висловлення, прислів'я та приказки. Більшість із них користуються великою популярністю та вживається в навчальному процесі у закладах вищої освіти як один із засобів здобуття знань, умінь, навичок з навчальної дисципліни та підвищення рівня якості знань студентів. У розмовній мові висловлення - це найменша одиниця мови, безперервний фрагмент, що починається і закінчується чіткою паузою. У розмовній мові висловлення мають низку особливостей, включаючи паралінгвістичні ознаки, зокрема вираз обличчя, жестикуляцію та поставу. До просодичних особливостей належить наголос, інтонація та тон, а також еліпсис - це слова, які слухач вставляє у розмовну мову, щоб заповнити так звані прогалини.

Відомий дослідник-лінгвіст Адмін (Admin) підкреслює, що висловлення можна сприймати як одиницю мови. Їх можна виокремити як частину мови між паузами і тишею. Зазвичай це стосується розмовної мови. Цю особливість розглядається як різниця, яка існує між реченням і висловленням. Висловлення можуть зазначатися одним словом, групою слів, навіть повним реченням. У лінгвістиці розмовні слова між двома паузами називаються висловленням (Admin, 2015).

В. А. Упен (В. А. Upen) зазначає, що висловлення - це найменша одиниця мови, яку можна визначити як «природну одиницю мови, обмежену вдихами або паузами», яка назавжди передає повне значення і смисл. Висловлення можуть зазначатися пунктом, одним словом, паузою і навіть змістовим абзацом (Upen B. A., 2018). На нашу думку, це визначення варто розширити і додати, що висловлення можуть зазначатись і невеликим реченням 3 особливим семантичним значенням з різними тіньовими значеннями.

Розглянемо найбільш популярні англомовні висловлення, які мають витоки із стародавньої англійської мови і нині вживаються викладачами в навчальному процесі як у закладах освіти України, так і США, зокрема такі: «Ноrses for courses» («Коні для скачок (для своєї діяльності)» або «бути на коні»), «lf you pay peanuts, you get monkeys» («Платите горіхами (арахісом), отримуєте мавп»), «Why have a dog and bark yourself?» («Чому маєш собаку і гавкаєш сам?»), «Let's cross that bridge when we come in» («Перейдемо той місток, коли до нього підійдемо»), «If уоu fly with crows, you'll get shot with the crows» («Якщо летиш з воронами, будеш застрелений з воронами»). Безумовно, знайти адекватний переклад цих висловлень у нашій рідній мові дуже важко, тому ми зробимо спробу розтлумачити їхнє значення, взявши за основу висловлення в автентичній літературі, зокрема англійській та американській.

Розглянемо висловлення «Horses for courses» («Коні для скачок (для своєї діяльності)», тобто «бути на коні», майстерно виконувати свій вид діяльності). Це висловлення вживають для того, щоб показати професійні знання, уміння навички фахівців, які кваліфіковано працюють на виробництві. В англійській та американській літературі воно вказує на різновидність діяльності механізмів та фахову придатність спеціалістів, наприклад: пральна машинка створена для прання білизни, посудомийна - для миття посуду, вантажівка - для перевезення вантажу. Спеціалісти різних професії мають фахові знання, уміння, навички, здібності, які необхідні для спеціальної сфери діяльності, зокрема: педагоги навчають дітей у школах, університетах; артисти працюють на сцені, виступають з концертами; лікарі лікують хворих, рятують життя людей. Усі вони виконують свою роботу кваліфіковано за певним фахом і відповідно до призначення, тобто вони «на коні».

Розглянемо діалог між двома друзями, проаналізуємо його і підтвердимо значення цього висловлення. Один 3 них - Піт (Pit), який каже товаришеві: «Добре, що я виріс у сім'ї азартних гравців, усі в моїй родині захоплювалися скачками на конях, гарно їздили верхи і трималися в сідлі, крім мене. I в результаті цього я зібрав досить багато висловлень, що стосуються коней. Один з моїх улюблених - «коні для скачок» («бути на коні»)» (Gunningham G., \& 
Bell J., 2016, р. 164). Таким чином, Піт зауважив, що він не вміє їздити верхи на коні і не бере участі в азартних іграх, але він є шанувальником мови, фольклору і знавцем цього висловлення.

Інший приклад було знайдено на сторінках веб-сайту в Інтернеті приблизно з таким же значенням: «ені дали роботу в управління статистики, що мені, особисто, вважається надзвичайно нудною. Але я маю досвід з математики і люблю працювати з цифрами. Я повинен робити цю роботу добре, кваліфіковано. Як кажуть - «бути на коні». Таким чином висловлення «Horses for courses» («коні для скачок (для своєї діяльності)», тобто «бути на коні», має два значення, а саме: гарно сидіти в сідлі, тобто вміти управляти конем, брати участь у скачках, а зворотний бік з тіньовим підтекстом - мати успіх у професійній діяльності, бути висококваліфікованим спеціалістом, фахівцем.

Розглянемо англомовне висловлення «lf you pay peanuts, you get monkeys» («Платиш горіхами (арахісом), отримуєш мавп»). З'ясуємо походження цього висловлення, що допоможе краще зрозуміти його повноцінний смисл і тіньовий бік уживання в мовленні. Арахіс належить до олійних культур сімейства бобових, щоб сформувати боби, квіти арахісу опускають у землю, де вони перетворюються у плоди. Це насіння має форму твердого горіха, який зазвичай їдять мавпи, і він символізує дуже невелику суму грошей. Виплачувати платню арахісом означає платити мізерну платню працівникам підприємства. Щодо мавпи, то це невелика тварина, яка живе на деревах у тропічних лісах і зазвичай передбачає дурість, але вона дуже полюбляє їсти саме ці горішки - арахіс.

Наведемо приклад із автентичної літератури, де головна героїня Кріс (Chris) підкреслює, що ії̈ улюбленим виразом є: «Платиш арахісом, отримуєш мавп». Це означає, що чим менше платні отримуєш за послугу, тим вона гіршої якості. у розмові із подругою Кріс зізнається: «Я мушу сказати своєму керівникові, що він дуже мало платить мені за роботу, але я не наважуюсь йому про це повідомити» (Gunningham G., \& Bell J., 2016, p. 164). Це висловлення вживається в англійській та американській літературі, щоб висвітлити, що люди працюють наполегливо і кваліфіковано, але іноді бояться сказати правду своєму керівникові, який платить мізерну зарплату, бо він жадібний і скупий. Можливо, вони не хочуть вимагати більшої платні, оскільки відчувають прогалини у своїх знаннях і не впевненні у своїх здібностях і кваліфікації. Натомість це висловлення вказує на якість виконання послуг: якщо послугу здійснено некваліфіковано, тоді і сплачено менше. Якщо на виробництві працюють некомпетентні та некваліфіковані працівники, тому його керівництво не оцінює роботу своїх спеціалістів належним чином. Фахівці, які оцінюють свої знання, уміння, навички на вищий рівень, зазвичай змінюють місце роботи, навіть їдуть до інших міст, щоб отримати вищу зарплату (The Free Dictionary, 2018).

Таким чином, ми з'ясували, що висловлення «платиш арахісом, отримуєш мавп» переважно вживається 3 негативним значенням, щоб закликати керівників підприємств платити працівникам вищу заробітну плату за якісно виконану роботу і висміяти тих, хто платить гроші своїм підлеглим за високий рівень знань, умінь, навичок у професійній діяльності. Цей вислів широко поширений у Великобританії, де його вживають із тіньовим смислом, щоб висміяти мізерну платню, отриману фахівцем за професійно виконану роботу.

Цікавим є висловлення «Why have a dog and bark yourself?» («Чому маєш собаку і гавкаєш сам?»), що вживають у мовленні з метою підкреслити, що фахова й обізнана людина у свої справі використовує інших для виконання поставленого завдання. Натомість навіщо витрачати свої сили і час, коли можна попросити товариша, подругу, ще когось, хто це зробить і зробить навіть трохи краще. Скористаємося прикладом з автентичної літератури, що вказує саме на основне значення цього висловлення. Головна героїня Лінн (Lynn) зазначає, що це її улюблене висловлення, вона запозичила його в матері і вживає у своїй розмові, діяльності, оскільки не дуже працелюбна людина. Лінн повідомляє, що має на підприємстві працівників, яких може попросити про послугу. На виробництві склалась ситуація, що терміново потрібно подати оголошення щодо розпродажу товарів, термін дії яких скоро завершується. На прохання виконати потрібну справу вона відповіла: «Нехай Кейт (Kate) напише це оголошення». Попри те, що Лінн працює у відділі реклами, вона звернулася до подруги виконати завдання. Висловлення «Чому маєш собаку і гавкаєш сам?» має і тіньовий бік у спілкуванні. Так, до прикладу, хлопець Кейт - «фантастичний кухар», але дівчина часто готує сама, тому її запитують: «Чому ти сама готуєш?». Наразі вона відповідає: «Чому маєш собаку і гавкаєш сама» (Gunningham G., \& Bell J., 2016, p. 164). Цей приклад відображає те, що Кейт, можливо, і не дуже добре готує (порівняно із хлопцем-кухарем), але вона хоче справу виконати самостійно і не турбувати інших, бо їй подобається готувати і вона не полюбляє просити про допомогу.

Наступні наші приклади висвітлюють приблизно те ж значення. у барі відпочивала компанія молодих людей і одна дівчина хотіла віднести посуд, але їй заперечили: «Просто залиште келихи на столі - співробітники бару їх заберуть. Зрештою, «Чому маєш собаку і гавкаєш сам?». Еллен (Ellen) розповідає своїй подрузі: «Прибиральниця кожного вівторка прибирає в мене в квартирі, зокрема витирає пил, миє підлогу, але я завжди її перемиваю. Джейн (Jane) каже подрузі: «Не будь дурною, Еллен, чому маєш собаку і гавкаєш сама?» (The Free Dictionary, 2018).

Таким чином, висловлювання «Чому маєш собаку і гавкаєш сам?» широко використовується в усному мовленні, зокрема в розмовах між керівниками, які можуть виконувати роботу самостійно і кваліфіковано, але доручають їі виконання своїм підлеглим не тому, що бракує у них часу, а тому, що не дуже полюбляють працювати. Інший бік цього висловлення вказує на працю обслуговуючого персоналу, зокрема прислуги. Символ собака характеризує кваліфікованого і знаючого фахівця, такого, що вже «з'їв собаку» і має невичерпний досвід у професійній діяльності.

Висловлення «Let's cross that bridge when we come in» («Перейдемо той місток, коли до нього підійдемо») не дуже вживається британцями в розмові, проте люди - не носії англійської мови - у захопленні від його значення. Це висловлення вживають, щоб застерегти, що не варто планувати заздалегідь виконання дії, коли важко передбачити iї результат. Саме слова Клавдії (Claudia) підкреслюють таке значення: «Ну, простіше кажучи, вам не варто хвилюватися про стан справи, виконання дії якої не можете передбачити у майбутньому» (Gunningham G., \& Bell 
J., 2016, р. 164). Наведемо кілька прикладів, що підкреслюють таке тлумачення і вказують на застереження та непередбачений результат подій у подальшому.

Молоде подружжя зібралось у подорож. Красивий і витончений юнак Алан (Alan) запитує: «Де ми зупинимось сьогодні ввечері?» Його супутниця Джейн (Jane) поважно й дотепно відповідає: «У наступному місті». Алан на те: «Що будемо робити, якщо не буде місць у готелі і вони будуть перенаповнені?» Джейн у відповідь: «Перейдемо той місток, коли до нього підійдемо» (The Free Dictionary, 2018).

У відділку поліції не можуть відкрити кримінальної справи через відсутність доказів і молодий офіцер, що проходить практику Мартін (Martin), запитує: «Я гадаю, якщо дійсно з'явиться більше доказів, нам, можливо, доведеться розглянути питання про повторне відкриття справи, чи не так?». «Ну, ну», - відповідає досвідчений полковник Кроуфорд (Crawford). - «Перейдемо той місток, коли до нього підійдемо».

Підліток-хлопчик запитує в мами: «Чи зможу я стати солдатом, коли виросту?» Мама відповідає: «Перейдемо той місток, коли до нього підійдемо» (The Free Dictionary, 2018).

Таким чином, висловлювання «Перейдемо той місток, коли до нього підійдемо» вживається, щоб підкреслити думку, яка висвітлює смисл, що не все можна планувати заздалегідь, особливо ті справи, події, результат яких важко передбачити в подальшому.

Це висловлення вживають викладачі протягом навчального процесу, коли вони добирають навчальний матеріал, адаптують його, намагаються доступно пояснити і донести потрібну інформацію до розуміння студентів, але юнаки та дівчата не завжди докладають своїх зусиль, щоб вивчити його або вчасно виконати завдання. Таким чином викладачі говорять: «Перейдемо той місток, коли до нього підійдемо», тобто дочекаємося семінарських занять, сесії, коли студенти докладуть максимум зусиль, щоб опанувати навчальним матеріалом і дати ґрунтовні відповіді на поставлені завдання.

Заслуговує на увагу висловлення «If you fly with crows, you'll get shot with the crows» («Якщо летиш з воронами, будеш застрелений з воронами»), що часто вживається у спілкуванні і підкреслює високий рівень ризику, небезпеки або ймовірність вигоди, винагороди. Це висловлення застерігає, що потрібно вчасно зупинитись, переосмислити свої вчинки, якщо потрапили до нехорошої компанії. Вважливо вибрати компанію людей, які дотримуються принципів чесності, доброти, справедливості. Таким чином, вибір компанії і друзів - це дуже важливо, бо, ідучи по життю разом із хорошими людьми, ми намагаємося рівнятися на них, переймаємо манери спілкування і поведінки. Найбільша проблема юнацтва в тому, що молоді люди не дуже полюбляють критику і прислухаються до неї, а намагаються відстоювати власну думку, за прикладом більшості своїх однолітків. І внаслідок цього, зокрема невдалого вибору компанії, потрапляють до групи людей із поганими манерами. Їм подобається бути серед «крутих» хлопців та дівчат, вони в захопленні від спілкування з ними, але з часом розуміють, що спілкування з такими друзями призводить до грубого і неадекватного впливу на них. Проте не так легко залишити таку компанію людей, тому і говорять: «Якщо летиш з воронами, будеш застрелений з воронами».

Символ ворон вибрано тому, що це міфічний птах, який символізує вітер, морок зла і лиха і водночас сонячне добро і мудрість. У англійській мові розрізняють цих птахів, зокрема ворона (crow) і ворон (raven) тому, що ворон не $€$ «чоловік ворони», а окремий вид птахів, якому притаманні риси жіночої і чоловічої статі. Зазвичай ворон живе зграями в лісах, степах, горах і пустелях, саме тому його вважають мешканцем глухих місць. Натомість ворона (ворони) заселяють усі дерева парків і будинків, часто б'ються і влаштовують свої пташині галасливі суперечки та бійки.

Розглянувши деякі англомовні висловлення, варто звернути увагу на українські приказки, прислів'я, які відображають характер носіїв мови, їх етнічні особливості, історію країни та її народу. Це допомагає українцям відчути подих власної долі, історію розвитку мови, за допомогою якої можна вживати висловлення, вести розмову на будь-яку тему, передати колорит народу і нації. Українські висловлення мелодійні, вони вишиті різнобарвними кольорами: цвітом вишні та яблуні, маргариток і калини. Найпоширеніші з них вживаються в навчальному процесі, щоб підкреслити статус викладача та студентів, обов'язки педагогів і зобов'язання молодих людей, зокрема ставлення до викладання і вивчення навчальної дисципліни та опанування навчальним матеріалом.

Розглянемо одне з найпоширеніших з-поміж викладачів і студентів висловлення «Назвався грибом - стрибай до кошика», яке вживається як у повсяқденному мовленні, так і в навчальному процесі. Основний смисл цього висловлення підкреслює реальну занятість людей у суспільстві, зокрема збирання грибів та приготування смачних страв. У навчальному процесі його вживають, з одного боку, щоб висвітлити роль викладача, його педагогічну діяльність, зокрема вміння викладати і пояснити навчальний матеріал, а з іншого - ґрунтовне опанування студентами навчальною інформацією. Якщо обрано професію вчителя, значить, потрібно належним чином навчати молодь, обрано професію лікаря - професійно лікувати хворих, а студентам - ґрунтовно опановувати навчальним матеріалом, бо вони саме ті «гриби», хто повинен зануритися в інформаційний потік - стрибнути до кошика знань.

\section{ВИСНОВКИ ТА ПЕРСПЕКТИВИ ПОДАЛЬШИХ ДОСЛІДЖЕНЬ}

Підсумовуючи вищезазначені англомовні висловлення, варто виокремити їх важливу роль у формуванні і розвитку мовленнєвих навичок студентів, бо вони збагачують будь-яку мову, сприяють розвитку комунікативних умінь, розвивають і формують думки молодих людей. Висловлення вживаються для вираження думок, приховування витонченого смислу, зокрема, щоб замінити думку і переосмислити ї̈ важливість, досягати взаєморозуміння у спілкуванні. Висловлення, зокрема англомовні, мотивують студентів до ґрунтовного опанування навчальним матеріалом з певної дисципліни, творчого мислення, переосмислення інформації, зокрема розуміння основного і тіньового їхнього смислу. 


\section{СПИСОК ВИКОРИСТАНИХ ДЖЕРЕЛ}

Admin. Sentence vs Utterance. Difference between sentence and utterance (February 19, 2015). Retrieved from: /https://mww. differencebetween.com/difference-between-sentence-and-vs-utterance/

Upen, B.A. What is an utterance. Difference between sentence and utterance (August 26, 2018). Retrieved from: http://pediaa.com/ difference-between-sentence-and-utterance

Gunningham, G., \& Bell, J. Dialogues. (2016). Fase2fase. Cambridge.

The Free Dictionary. (2018). Horses for courses. Retrieved from: http://idioms.thefreedictionary.com/lf+you+pay+peanuts, +you+get+monk eys

The Free Dictionary. (2018). Horses for courses. Retrieved from: http://idioms.thefreedictionary.com/Why+keep+a+dog+and+bark+yourse If\%3F

The Free Dictionary. (2018). Horses for courses. Retrieved from: http://idioms.thefreedictionary.com/cross+that+bridge+when+one+come s+to+it 